\section{Caught in a propaganda war}

\section{London}

CROATIA's leading research centre has been dragged into the bitter conflict between the breakaway republic and the Serbiandominated Yugoslav government. The federal government's Tanjug press agency and Belgrade's television station and leading newspapers have accused the Ruder Boškovic Institute in Zagreb of working secretly to produce an atomic weapon for use against Serbia. Western physicists familiar with the Ruder Bošković Institute dismiss the claim as impossible, but its director-general, Krunoslav Pisk, fears that the propaganda offensive is a prelude to an aerial bombardment of his institute.

The accusations, which surfaced in the Belgrade media last month, implicate the Ruder Bošković Institute in an alleged Croatian plot to produce a nuclear weapon with help from South Africa. But Pisk protests that his institute is devoted entirely to peaceful activities, including theoretical physics, radioactive waste disposal and food irradiation. In any case, he says, the Bošković institute lacks the high-technology hardware needed for weapons research and production. The institute's nuclear equipment is limited to a cobalt source, a Van de Graaff generator and an ageing accelerator, Pisk says. A cyclotron and a neutron source are now defunct, he adds.

Researchers in the West back Pisk's description of the institute. "It's absolutely ridiculous" to suggest that the Bošković institute could be involved in a weapons project, says Edward Bilpush, a nuclear physicist from Duke University in North Carolina who has visited Zagreb on many occasions. "I have complete access whenever I go there."

Walter Greiner, a theoretical physicist at the University of Frankfurt who last visited the institute in May, shortly before Croatia's secession from Yugoslavia, says that the Bošković institute's experimental physics equipment is too primitive to support an atomic weapons programme (the institute's main strength is in theoretical physics).

Pisk's fear is that the accusations made in the Belgrade media are part of a campaign to justify a planned military attack against his institute - which has so far escaped unscathed from the limited air strikes against Zagreb. The Bošković institute is Croatia's only research centre of international standing, and Pisk estimates that it represents 60 to 70 per cent of the entire scientific infrastructure of the republic. Pisk believes that the federal government wishes to destroy Croatia's infrastructure so that the republic can no longer function independently of the federal government.

In an attempt to counter the claims emanating from Belgrade, Pisk has written to Hans Blix, director-general of the International Atomic Energy Agency (IAEA) in Vienna, saying that the institute would welcome a team of IAEA inspectors. But Blix's hands are tied by IAEA's constitution, which says that he can respond only to complaints made by IAEA members. As the breakaway former Yugoslav republics are not represented within IAEA, Blix has been able only to contact the Yugoslavian foreign ministry saying that IAEA is willing to inspect the Bošković institute, should the Belgrade government request it to do so. Not surprisingly, the federal government has made no such request.

That the Bošković institute should become embroiled in a conflict hingeing on opposing nationalist ambitions is sadly ironic. Bilpush says that for many years the institute "was a gateway to the West for the East", bringing together researchers who were otherwise separated by the political division of Europe. Both Western and Eastern bloc scientists could travel freely to communist, but non-aligned, Yugoslavia, so the institutes' researchers were able to organize regular international meetings in Zagreb and in other cities throughout Yugoslavia.

Peter Aldhous

\title{
A chip off some old rocks
}

\section{Washington}

THROUGH a combination of ingenuity and a little luck, mission scientists at the Jet Propulsion Laboratory in Pasadena, California, were able last week to bring down to Earth a few frames of the many pictures taken by the spacecraft Galileo as it passed within 10,000 miles of the asteroid Gaspra. Galileo, due to arrive at Jupiter in 1995, is in working order except that its high-gain antenna failed to open, limiting its data transmission to a less powerful telemetry link that transmits at the meagre rate of 40 bits per second.

It was originally intended that the pictures of Gaspra, stored on tape aboard the spacecraft, would not be seen until late next year when Galileo is due to pass close by the Earth to gain some final momentum before swinging off into the outer solar system. But project scientists realized soon after the 20 October encounter with Gaspra that their estimate of its position relative to the spacecraft was more accurate than they had expected, so that the asteroid was fully imaged in the central frame of a three-by-three mosaic taken to ensure adequate sky coverage. After a test transmission, they were able to determine which section of the taped data contained the complete image. Even so, it took about 20 hours to receive this one image.

Gaspra is a chunk of rock about 15 kilometres across at the broadest part. It resides in a section of the asteroid belt, beyond Mars, where the expected lifetime between collisions is some hundreds of millions of years. The amount of cratering visible is consistent with such an age, and the irregular shape lends weight to the idea that asteroids are fragments created by the collision and disruption of larger

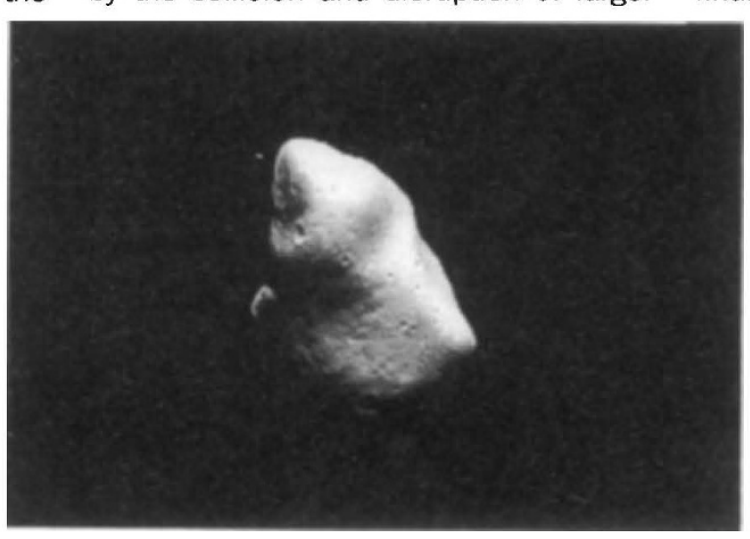

parent bodies that formed at the same time as the planets.

The complete set of pictures taken by Galileo includes images at different wavelengths and at higher resolution. When all of the data have been transmitted to Earth, it will be possible to create a true colour picture of the asteroid, which may help in determining its surface structure and composition. But that will have to wait. As Galileo recedes from the Earth, the transmission rate will fall to a paltry 10 bits per second, and will not come back up to 40 bits per second until next April, as it nears the Earth en route to its final swing towards Jupiter. In the meantime, mission scientists will try once again to release the jammed antenna by switching off some of the spacecraft's instrumentation and rotating the antenna side away from the Sun for two days. The drop in temperature, it is hoped, will dislodge alignment pins that are keeping the ribs of the antenna from opening out. Previous cooling manoeuvres in July and August failed to free the antenna, but mission managers believe that they did cause the pins to "walk towards freedom".
David Lindley 